Mukhripah Damaiyanti ${ }^{1}$, Dwi

${ }^{1}$ Faculty of Health Science, Universitas Muhammadiyah Kalimantan Timur Email: muda101180@gmail.com Rahmah Fitriani ${ }^{1}$

\section{The Relation of Educational Level, Academic Achievement (GPA) and Depression Among Public School Adolescent}

\begin{tabular}{ll}
\hline Info Artikel & $:$ \\
Masuk & $:$ 30 September 2017 \\
Revisi & $: 15$ November 2017 \\
Diterima & $: 30$ November 2017 \\
DOI Number & $: 10.18196 /$ ijnp. 1365
\end{tabular}

\begin{abstract}
Depression is a worlwide mental health problem psychology disorder in adolescent. Depression is one of the emotional problems, hopelessness and helplessness are its main causes. The other word, depression is aprevalent problem among college's student ability to perform activities of daily life. This descriptive correlation study aimed to describe the relation of educational level, academic achievement (GPA) and depression among public school adolescents of Samarinda municipal, East Kalimantan province, Indonesia. A total of 552 adolescents in senior high school aged between 14-19 years were recruited through stratified cluster sampling. The instruments was The Center for Epidemiologic Studies Depression (CES-D). The data were analyzed by statistical method including $t$-test, Chi-square, and Pearson correlation. The result showed the prevalence of depression in this sample of Indonesian adolescents was $52.7 \%$. Adolescent females showed almost equal prevalence of depression than adolescents' males (26.6\%, 26.1\%), respectively. There was significant relationship between adolescents' depression and educational level $\left(X^{2}=8.039, p\right.$ value $=$ 0.018 ). Specifically, based on the findings suggest interventions program to reduce depression in adolescents by giving health education with specific mental health in school. Some programs a re able to do in school such as counseling center, stress management program, time management, and screening about negative life events. This strategy need to include the participation of other personnel such as class coordinator and health workers to be successful of program.
\end{abstract}

Keywords: adolescents, depression, public high school

\section{Introduction}

In the rapid world changes nowadays, a significant contributor to the global burden of disease and affects people in all communities across the world is depression (WHO, 2012). Depression is one of the emotional problems, hopelessness and helplessness are its main causes. The other word, depression is aprevalent problem among college's student ability to perform activities of daily life. (Khursid et al, 2015). According to National Institute of Mental
Health (2012) found that many students experience the first symptoms of depression during their college. More than 1.75 billion proportion around the world is young people with aged from 10 and 24 years (WHO, 2008). In young people, the prevalance of depression is 0.3 percent in preschool children and 2 percent in school children as well as 4-8 percent in adolescents (Sabate, 2004). Meanwhile, based on between the ages of 13 and 18 year-old suffering 


\section{NONRSSINAN PRACTICES}

depression have $8.4 \%$ and $15.9 \%$, respectively (Wagstaff, 2012).

Ministry of Health of Indonesia (2009) mentioned that adolescents suffering depression increased gradually from 43 million or $19.61 \%$ adolescents aged from 10 to 19 years to 62 million of all population between 2006 and 2008, respectively. Depression has some significant impact for adolescents. They prepare for their transition to adult life (McCan, Lubman, \& Clark, 2012) and also depression in youth presents a certain burden for adolescent (Perry et al. 2007). Based on The World Health Organization in world health report explain that depression called The Silent Epidemic is an outbreak of a disease that may not be perceived directly as a result, but a result of the disease, which then burst and become major contributors to the cause of human death. Friends, peers, teachers as well as parents are group of population that receive the effects of depression from adolescent. (Zgambo et al, 2012) and negative impact on school performance (UNICEF, 2004). Depression in young people are associated with poor acade mic performance, social dysfunction, substance abuse, and attempted and completed suicide (Brent, 2002), felt sad or hopeless for a prolonged period of time, to the point that these feelings impaired from doing usual activities (CDC, 2011), the occurrence of substance use, nonsuicidal selfinjury, and suicide ideation or behavior as well as with depression, suicidality, and impaired functioning later in life (Taliaferro et al. 2013), experience emotional suffering and proble $\mathrm{ms}$ in daily living and functioning, such as decreased participant in social activities or impairment in social and interpersonal relationship (Corona et al. 2013; Liu et al. 2000; Woodgate, 2006), difficulties with peer relationship, low selfesteem including body image disturbance (McPhee \& Andrews, 2006), as well as potential disharmony at home (Farmer, 2002).

Research shows that the increasing rates of depression in adolescents because adolescents experiencing school problems (Shaffer \& Waslick, 2002, Sriphet, 2001, Wagstaff \& Polo, 2012). Common co-occurring problems for depressed children and adolescent are academic underachievement, school attendance problems, and school failure (Hammen et al. 1999) including rising amount of schoolwork, assignment deadlines, and exams (Vatanasin et al. 2012). When adolescents got depression, they are ofte $n$ face problems in their school not only academic progress but also themselves like loss of energy and motivation that needed in academic achievement so that they cannot concentrate and focus in the classroom during study in the school. (Shaffer \& Waslick, 2002; Sriphet, 2001). At times, depression is one of the common psychiatric diagnoses that make adolescents to school refusers. Adolescents leave hopes to study and success in the school as well as think how to reach academicachievement. Sometimes, based on condition and situation they decided to withdrawn from attending school (King \& Bernstein, 2001). And also, depressed adolescents commonly have difficulties interacting with their same-age peers. Depressed adolescents may have more difficulty developing effective social problem solving, leading to a greater chance of being rejected or perceived as less competent in a variety of areas by their peers (Shaffer \& Waslick, 2002). Hence, adolescents who experience depression are heavy problems to them (Wagstaff, 2012).

In Indonesia, based on National Education System (2013) educational level in high school consist different grade from grade 11 to grade 12 . Curriculum used is a competency-based curriculum that includes subjects and student learning loads every class is different. For instance, students who study in the grade 12 they must prepare to follow the last study examination that called in Indonesia is national exam. 3rd grade high school students in particular as examinees often view the national exam as a scary thing because the standard graduation rate continues to increase. Simamora (2014) conducted a research about description of adolescent depression in high school found that adolescent who in the grade 12 experience depression than adolescents who study between grade 10 and 11 . Additionally, research by Poulin, Hand, Boudreau \& Santor (2005) showing the 
result that predictor of depression risk is academic performance for males and females adolescents.

\section{Methods}

The design of this research was a descriptive correlation. Sample of the present study was consisted of 552 students ( 276 male, 276 female) using calculated Daniel Formula (Daniel, 1999, as cited Zaied, 2014), which was selected by startified cluster sampling with age 14 to 19 years from three public colleges of city Samarinda, East Kalimantan.

In this study focus to public high school because the first and main difference between public schools and private schools is the legal basis. Although publicand private schools have services which is the same, but they have different legal umbrella. Private schools have to obey the laws foundation (Law No.28 year 2008), while the public schools refer to the legislation of the National Education System (Law No.20 year 2003), article 50 clause 6 (Fajar, 2011).

There is one part of questionnaire to assess demographic data of respondents. It involved age, sex, educational level, educational achievement (GPA), parental education and occupation as well as family income.

The Centerfor Epidemiologic Studies Depression (CES-D) Scale to measured depressive symptoms of the adolescents and consists of 20 items (Radloff, 1977). There are four component of depression, including depressed effect, positive affect, somatic and retarded activity, and interpersonal relationship. These instruments, all of answer in each items question respondents will be judged during the past week how often they experienced depressive symptoms. There are responses options on a 4-point scale: 0 (rarely or none of the time/less than once a week), 1 (some or a little of the time/1-2 days a week), 2 (occasionally or moderate amount of time/-4 days a week), or 3 (most or all of the time/5-7 days a week). A total CES-D score range betwe en zero and 60, showed level depression that greater if have the score is higher. If individual indicate a high level of depressive symptoms, they have scores of 16 and above and 23 or more reflected significant depression. Several researchers translated the CES-D into the Indonesia language and found to be valid as a screening tool for depression in adolescent. Hence, the Indonesia version of CES-D of the Siwanto which cut-off point score at 20 was be used in this study.

Descriptive statistics of frequency, percentage, mean, and standard deviations were calculated to analyzed the socio-demographic and the prevalence of depression. A bivariate analysis used the Pearson correlation for interval variables and Chi-Square for dichotomous variables.

\section{Results}

The mean age of respondents was 16.31 which similar between male and female. The majority $(68.7 \%)$ of subjects were in aged $16-17$ years with male higher of percentage than female. Meanwhile, the $14-15$ years group was largest group with female than male. Most (85\%) of participants was Islam. Female had slightly higher educational achievement (GPA) compare d than male. Mostly male had GPA between $2.00-$ 2.99 while female had GPA from $3.00-4.00$. The fathers were the heads of household found mostly amongst the respondents. About $85 \%$ of respondents reported that they live with married parents and nuclear family characteristic with two parents (47.8\%). Half (50.4\%) of respondents have household head completed senior high school with the largest worked of them as business and ( $45.8 \%)$ average income per month of household head around 80 USD. 


\section{NDONESANOUNPNANG \\ PRACTICES}

Table 1. Number, percentage and depression classification of the respondents classified by depression cutoff point

\begin{tabular}{lccccc}
\hline Depression scores & $\begin{array}{c}\text { Total }(\mathbf{n}=\mathbf{5 5 2}) \\
\mathbf{n}(\mathbf{\%})\end{array}$ & $\begin{array}{c}\text { Male } \mathbf{( n = 2 7 6 )} \\
\mathbf{n}(\mathbf{\%})\end{array}$ & $\begin{array}{c}\text { Female }(\mathbf{n}=\mathbf{2 7 6}) \\
\mathbf{n}(\mathbf{\%})\end{array}$ & $\mathbf{T}$ & $\mathbf{P}$ \\
\hline CESD $<20$ & $261(47.3)$ & $132(23.0)$ & $129(23.4)$ & & \\
CESD $\geq 20$ & $291(52.7)$ & $144(26.1)$ & $147(26.6)$ & 0.216 & 0.398 \\
& $\bar{x}=20.68$ & $\bar{x}=20.45$ & $\bar{x}=20.92$ & & \\
& $S D=6.584$ & $S D=6.395$ & SD $=6.771$ & & \\
\hline
\end{tabular}

${ }^{*} \mathrm{P}=$ statistical significant $\alpha \leq .05$

Table 1 showed that the prevalence of depression in this sample of Indonesian adolescents was $52.7 \%$. Interestingly, the percentage of depression both of male and female is almost equal $(26.6 \%, 26.1 \%$, respectively). And the result found there was no significant difference mean score of depression between male and female.

Table 2 Number, percentage and depression of the respondents between male and female based on educational level

\begin{tabular}{cccc}
\hline $\begin{array}{c}\text { Educational } \\
\text { Level }\end{array}$ & $\begin{array}{c}\text { Total } \\
\mathbf{n}(\%)\end{array}$ & $\begin{array}{c}\text { Depression } \\
\mathbf{n}(\%)\end{array}$ & $\begin{array}{c}\text { No Depression } \\
\mathbf{n}(\%)\end{array}$ \\
\hline Grade 10 & $186(33.6)$ & $84(15.2)$ & $102(18.4)$ \\
Grade 11 & $184(33.3)$ & $98(17.7)$ & $86(15.6)$ \\
Grade 12 & $182(33.0)$ & $109(19.7)$ & $73(13.2)$ \\
Total & $552(100)$ & $291(52.7)$ & $261(47.3)$ \\
\hline
\end{tabular}

As shown in table 2, these results indicate that the prevalence of depression differs based on educational level in high school. Respondents whose in grade 10 have percentage of no depression slightly higher than percentage of depression. However, respondents in grade 11 and 12 have percentage of depression more than respondents whose no depression. And as the grade advanced (grade 12), the percentage of depression showed a tendency to increase.

Table 3 Means and standard deviations of the educational achievemnet (GPA) between male and female

\begin{tabular}{lcccccc}
\hline \multirow{2}{*}{ Variables } & $\begin{array}{c}\text { Total } \\
(\mathbf{n = 5 5 2 )}\end{array}$ & $\begin{array}{c}\text { Male } \\
(\mathbf{n = 2 7 6 )}\end{array}$ & $\begin{array}{c}\text { Female } \\
(\mathbf{n = 2 7 6 )}\end{array}$ & & & \\
\cline { 2 - 7 } & Mean (SD) & Mean (SD) & Mean (SD) & $\mathbf{9 5 \%} \mathbf{C l}$ & $\mathbf{T}$ & $\mathbf{P}$ \\
\hline Educational & 2.39 & 2.30 & $2.49(0.529)$ & $-0.277-$ & -4.169 & $0.000^{*}$ \\
achievement (GPA) & $(0.539)$ & $(0.533)$ & & 0.100 & & \\
\hline
\end{tabular}

${ }^{*} \mathrm{P}=$ statistical significant $\alpha \leq .05$ 
Table 4 Means and standard deviations of educational achievement (GPA): A comparison between depression and no depression

\begin{tabular}{lcllccc}
\hline \multirow{2}{*}{ Variables } & $\begin{array}{l}\text { Total } \\
(\mathbf{n = 5 5 2 )}\end{array}$ & $\begin{array}{l}\text { Depression } \\
(\mathbf{n = 2 9 1 )}\end{array}$ & $\begin{array}{l}\text { No Depression } \\
(\mathbf{n = 2 6 1 )}\end{array}$ & & & \\
\cline { 2 - 7 } & Mean (SD) & Mean (SD) & Mean (SD) & $\mathbf{9 5 \% ~ C l}$ & $\mathbf{t}$ & $\mathbf{P}$ \\
\hline Educational & 2.39 & 2.40 & 2.39 & $-0.075-$ & 0.328 & 0.743 \\
achievement (GPA) & $(0.539)$ & $(0.544)$ & $(0.533)$ & 0.105 & & \\
& & & & & & \\
\hline
\end{tabular}

${ }^{*} \mathrm{P}=$ statistical significant $\alpha \leq .05$

As shown in Table 3, along with descriptive statistic for male and female and the result of $t$ test of selected variables between sexes. Differences mean between male and female were statistically significant was educational achievement (GPA). However, in Table 4, differences mean between depression had no statistically significant of educational achievement (GPA)

Table 5 Relationship educational level, educational achievement (GPA) and adolescents' depression using Chi-square and Pearson Correlation

\begin{tabular}{ccccc}
\hline \multicolumn{1}{c}{ Variables } & Value $\left(\mathbf{X}^{\mathbf{2}}\right)$ & Depression & \\
& & 8.039 & 2 & P-value \\
\hline 1. Educational level & & $\mathbf{R}$ & $0.018^{*}$ \\
& & & P-value \\
2. Educational achievement (GPA) & & 0.000 & 0.999 \\
\hline
\end{tabular}

${ }^{*} \mathrm{P}=$ statistical significant $\alpha \leq .05$

As shown in Table 5, educational level was significant related to adolescents' depression.

\section{Discussion}

The prevalence of depression in Indonesian adolescents was $52.7 \%$ which higher than study by Asmika et al. (2008) found that prevalence of depression in adolescents of senior high school in Malang district, Indonesia was $39.3 \%$. Apart from that, the prevalence was considerably higher when compared with studies of adolescents in other countries. For instance, the range of prevalence of adolescents depression from $10 \%$ $35 \%$ were Australia, America, the United Kingdom, Nigeria and Iran whereas the range of prevalence between 36 and 45 percent were Korea, China and Thailand (Busari, 2012, Costello et al. 2006, Hyun et al. 2009, McCan et al. 2012, Modabber-Nia et al. 2007, Walsh, 2009, Vatanasin et al. 2012).
Relationship between educational level and adolescent depression showed that there was relation in this study. There are many results of a study that found that students in high school to experience more severe depression by level of education (Asmika, 2008). The respondents were enrolled in the school setting that may stressors of both developmental task and their study. The participants in this study were studying in three high schools under jurisdiction of Department of National Education Indonesia and focus this study to public high school. Based on National Education System in Indonesia (2013) educational level in high school consist different grade from grade 11 to grade 12 and curriculum used is a competency-based curriculum. Even though they were studying in the same school environments but they received different subjects, curriculum 


\section{NUROSSSING \\ PRACTICES}

and burden in each level (Asmika, 2008). Exactly students in grade 12 , they must prepare the last examination that called in Indonesia is national exam that consequently experiences depression than students in grade 10 and 11 . Currently, education curriculum in Indonesia is heavy than other country (Kapiyani, 2016). Targeted curriculum that is too high, the climate is not conducive to learning, giving the task a very dense, and rigorous assessment system less fair and could be a factor causing depression factor derived from the curriculum (Alestelo et al. 2002). Likewise, strict application of school discipline and more prioritizing punishment, school climate that is less convenient, and facility and pre-learning tool is very limited also trigger the formation factors of depression in student who come from schools factors.

Considering their education achievement (GPA) it was found that there was no relationship with adolescent depression. This finding was supported by previous studies in in China (Chen \& Li 2000), in Indonesia (Septianto, 2014), and also in Iran (Shahmohammadi, 2014). According to Chen \& Li (2000) suggest that depression in adolescents schools in China not because of educational achievement, but because the process of school activities such as the number of assignments and homework. School adolesce nts are required to maintain attention and concentration during the process. In Indonesia, study by Septianto (2014) reported that one of reason adolescents get depression in the school is increasing the performance of study in the learning process in schools. Therefore, they think is not important about the last results in their learning. The most important how to adolescents in the school can get education through process. Also supported study by Shahmohammadi (2014) stated that depression among adolescents in Iran is not related with educational achievement in school but they have experience depression because school schedule is too crowded, students learning with too much content studied as well as how to prepare test. Related in this study find ing that study load, time pressure during study and problems in accomplishing tasks or essay were problems of study faced adolescent in school that related to depression.

\section{Conclution and Recommendation}

There most important to developing prevention and intervention program to reduce depression in adolescents is give health education with specific mental health in academic environments. Some programs able to do in the school such as stress management program and screening about negative life events. This strategy must include the participation of health workers and class coordinator to conduct the program in school.

\section{References}

Alestalo, A., Munnuka, T., \& Pukuri, T., 2002, Problems of young people in community psychiatric care. Journal of Psychiatric and Mental Health Nursing, 9, 33-40.

Asmika., Harijanto., \& Handayani, N., 2008, The prevalence of depression and description of psychosocial stressor in adolescent of senior high school in Malang district. Jurnal Kedokteran Brawijaya, 24,(1).

Brent, D. A., 2001, Assessment and treatment of the youthful suicidal patient. Ann $N Y$ Acad Sci, 932, 106-28.

Busari, A. O., 2012, Evaluating the relationship between gender, age, depression and academic performance among adolescents. Scholarly Journal of Education, 1(1), 6-12.

CDC, Youth Risk Behavior Surveillance-Unites States, Data of access 25/8/2014 http://www.cdc.gov/mmwr/pdf/ss/ss610 4.pdf

Chen, X., \& Li, B. S., 2000, Depression mood in Chinese children: development significance for social and school adjustment. Int J Behav Dev, 24, 472-479.

Corona, M., McCarty, C. A., \& Richardson L. P. Screening adolescents for depression. Data of access 5/9/2013 http://contemporarypediatrics.modernm edicine.com

Costello, E. J., Pine, D. S., Hammen, C., et al., 2002, Development and natural history of mood disorders. Biol Psychiatry, 52(6), 529-542.

Daniel, W. W., 1999, Biostatistics: A Foundation for Analysis in the Health Sciences ( $7^{\text {th }}$ ed). (New York: John Wiley \& Sons). 
Farmer, T. J., 2002, The experience of major depression: adolescents' perspectives. Issue in Mental Health Nursing, 23, 567585.

Hammen, C., Rudolph, K, Weisz, J., Rao, U., \& Burge, D., 1999, The context of depression in clinic-referred youth: Neglected areas of treatment. Journal of American Academic of Child and Adolescent Psychiatry, 38, 64-71.

Kapiyani., (2016) Efektifitas implementasi kurikulum 2013 pada enam sekolah sasaran SMA diKabupaten Bantul Daerah Istimewa Yogyakarta tahun pelajaran 2015/2016. Thesis. Universitas PGRI Yogyakarta.

Khursid, S., Parveen, Q., Yousuf, M. I., Chaudhry, A. G., 2015, Effects of depression on students' academic performance. Sci.int (lahore), 27(2), 1619-1624.

King, N. J., \& Bernstein, G. A., 2001, School refusal in children and adolescents: a review of the past 10 years. Journal of the American Academy of Child \& Adolescent Psychiatry, 40, 197-205.

Liu, X. C., Guo, C., Okawa, M., Zhai, J., Li, Y., Uchinyama, M., et al., 2000, Behavioral and emotional problems in Chinese children of divorced parents. Journal of American Academy of Child \& Adolescent Psychiatry, 39(7), 896-903.

McCann, T. V., Lubman, D. I., \& Clark, E., 2012, The experience of young people with depression: a qualitative study. Journal of Psychiatric and Mental Health Nursing, 19, 334-340.

McPhee, R., \& Andrews, J. W., 2006, Risk factors for depression in early adolescence. Adolescence, 41(163), 435-466.

Modabber-Nia, M-J., Shodjai-Tehrani, H., Moosavi, S-Y., et al., 2007, The prevalence of depression among high school and pre university adolescents: Rasht, Northern Iran. Arch Iranian Med, 10(2), 141-146.

KEMENTRIAN KESEHATAN REPUBLIK INDONESIA, Profil Kesehatan Indonesia tahun 2008.

NIMH, Depression and college students. Data of access 18/6/2014. https://www.nimh.nih.gov/health/public ations/depression-and-collegestudents/index.shtml
Perry, B. L., Pescosolido, B. A., Martin, J. K., et al., 2007, Comparison of public attribution, attitudes, and stigma in regard to depression among children and adults. Psychiatr Serv, 58, 632-635

Poulin, C., Hand, D., Boudreau, B., \& Santor, D, 2005, Gender differences in the association between substance use and elevated depressive symptoms in a general adolescent population. Addiction, 100, 525-535.

Radloff, L. S., 1977, The CES-D scale: A self-report depression scale for research in the general population. Applied Psychological Measurement, 1, 385-401.

Sabate, E., 2004, Depression in young peopleand the elderly. Working paper, The Priority Medicines for Europe and the World, a public Health Approach to Innovation.

Septianto, R., 2014, Hubungan antara tingkat depresi dengan nilai modul Clinical Reasoning I pada mahasiswa pendidikan dokter UIN Syarif Hidayatullah angkatan 2013. Universitas Islam Negeri Syarif Hidayatullah, Jakarta.

Siswanto., 2002., Pengaruh menulis pengalaman emosional terhadap symptom-simptom depresi pada mahasiswa. Fakultas Psikologi, Universitas Gajah Mada, Yogyakarta.

Shaffer, D., \& Waslick, B. D., 2002, The many faces of depression in children and adolescents. (Washington, DC: American Psychiatric Publishing)

Shahmohammadi, M., 2014, Depression on homesicknessamong Iranian students in University Malaya. Faculty of Medicine, University of Malaya.

Sriphet, C.., 2001, Factors influencing adolescent depression. Unpublished thesis, Mahidol University, Bangkok, Thailand.

UNICEF, The Children: Adolescents. Data of access 12/1/2014. http://www.unicef.org/china/children_8 77.htm.I

Vatanasin, D., Thapinta, D., Thompson, E. A., \& Thungjaroenkul, P., 2012, Testing a model of depression among Thai Adolescents. Journal of Child and Adolescent PsychiatricNursing , 25, 195-206. 


\section{NUDRSESAN ING \\ PRACTICES}

Wagstaff, A. E., \& Polo, A. J., 2012, Ethnicity and adolescent depression: prevalence, access to service and promising interventions. The Prevention Researcher, 19(4).

Walsh, L., 2009, Depression care across the lifespan. (London, U.K: The British Library).

Woodgate, R. L., 2006, Living in the shadow of fear: adolescents' lived experience of depression. Issues and Innovations in Nursing Practice., 261-269.

WHO, The global burden of diseaase, 2004 update. Data of access: 20/5/2014 http://www.who.int/healthinfo/global_b urden_disease/GBD_report_2004update full.pdf

WHO, Depression a global public health conce $r n$. Data of access: 20/5/2014 http://www.who.int/mental health/man agement/depression/who_paper_depres sion wfmh 2012.pdf

WHO, World health report. Data of access: 20/4/2018

http://www.who.int/whr/1995/media ce ntre/executive_summary1/en/index3.ht $\mathrm{ml}$

Zaied, M. B., Naim, A. M., \& Mekki, D. M., 2014, Development of logarithmic equations for statistical sample determination. Journalof Empirical Studies, 1(1), 23-29.

Zgamboo, M., Kalembo, F., Guoping, H., \& Honghong, W., 2012, Depression among Chinese children and adolescents: a review of the literature. International Journal of Child, Youth and Family Studies, 4(1), 442-457. 